九病虫研会報 $35 ： 3-4$ (1989)

Proc. Assoc. Pl. Prot. Kyushu 35：3-4 (1989)

\title{
鹿児島県におけるイネ縞葉枯病ウイルスによる 普通期水稲の感染時期
}

深町 三朗・井上 栄明 (鹿児島県農業試駼場)

\begin{abstract}
Period of infection by rice stripe virus during normal season rice culture in Kagoshima Prefecture. Saburo FuKamaCHI, Hideaki InOuE (Kagoshima Agricultural Experiment Station, Kagoshima 891-01)
\end{abstract}

九州に打けるイ 亦稿葉枯病は1959年に北部九州の山問 部と北部九州の平坦部の一部で主として早植栽培のイネ で多発生した。その捘1966年頃まで麦の収穫期と水稆の 植え付け期が接近している北部九州の山問部で発生を認 めていたが，同华 (1966年) 以降減少して，散見される 程度であった。1984年に沖縄県の石垣岛の二期水稲と鹿 児島県の南西部沿海地域で多発生し，1985年には九州西 部の普通期水稲で多発生した。これらの多発生は突発的 であると同時にセジロウンカ，トビイロウンカの飛来期 とほぼ重なり合う第2 世代成虫の移動性個体群に侬存し ていると言われている。そこで，その感染時期について 検討したので結果の概装を報告する。

\section{試験方法}

試験は1986〜1988年鹿児鼠県農業試験場の戋場で行っ た。イネ品種はニシホマレを供試した。箱育苗の稚花を $50 \mathrm{~m}^{2}$ のパイプハウスに 6 月 20 日固植した。パイプハウス は寒泠紗で被覆して，8月20日まで，10日問づつ寒冷紗 を除いた暴露区を 6 区設け，縞葉枯病の時則別感染率は 全株の発病の有無によって调查した。暴露後は被覆当日 と10日後に楽骫散布を行った。ヒメトビゥンカの飛来量 については闌場に設置したステッキートラップと地上 $10 \mathrm{~m}$ に設置したジョンソントラップでの捕捉虫を毎日調 龺した。

\section{結果および考察}

縞葉枯病の時期別感染率は1986年は 7 月中句暴露区で 感染株率 $1.9 \%$ を示し, 最も高く, 続いて7月下旬, 8 月上句も $1.2 \% ， 1.7 \%$ と長期に亘って高い感染率であっ た(第 1图)。1987年は7月下旬で0.8\%，1988年は7月 中勿で $1.8 \%$ を示し，主要感染時期は 7 月中一下旬で感 染率は 1〜2\%と少ないが，この主要感染期間は年に上 り長引くことが認められた。これらの結果は無防除田の
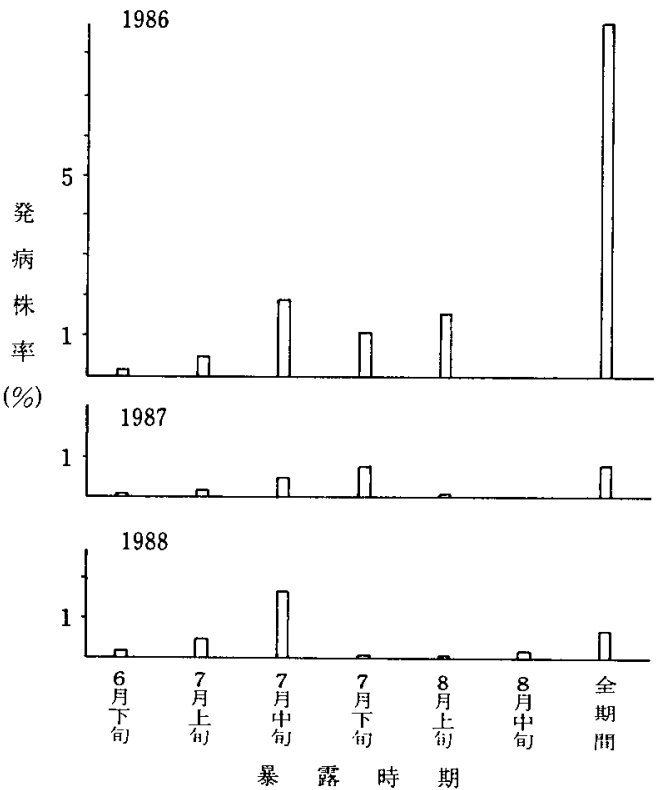

第1圆普通期水稲の\}ネ稿葉枯病の感染時期

発生推移とほぼ一致した(第 2 図)。その年の縞葉枯病 の発生には第一次感染株数の多少と, その後の圃場にお けるヒメトビゥンカの增殖が関与するものと思われる (第 2 図)。ヒメトビウンカの捕虫数と発病の相関関係 は低かったが，その中では移動性個体群より固場の侵入 個体群の相関関係が高かった（第 3 図）。侵入個体数と 発病の関係から，1986年の保毒虫率が高かったことが示 唆されたが、これらは第 1 世代の保毒虫率検定結果と一 致した(第 1 表)。普通期水稲での縞葉枯病の第一次の 主要感染時期は 7 月中〜下旬で, 感染率は保毒虫率が関 与していた。縞葉枯病の突発的発生の解明のためにヒメ トビウンカの移動性個体群については海外飛来も含めた 発生生態の解明が必要である。 


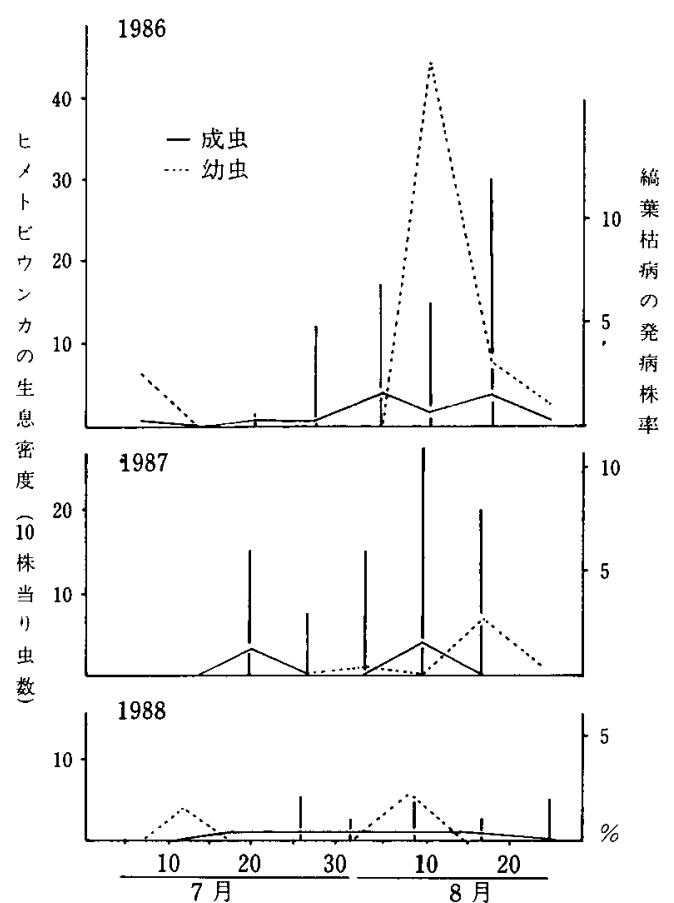

第 2 図普通期水稻のヒメトビウンカの生息状洗とイネ稿葉枯 病の発生状況

\section{引用 文 献}

1) 新海 昭 (1985) 植物防疫 $39: 503-507$. 2）奈須壮兆 （1960）九州病害虫防除技術推進資料 2：1-66. 九州病害虫

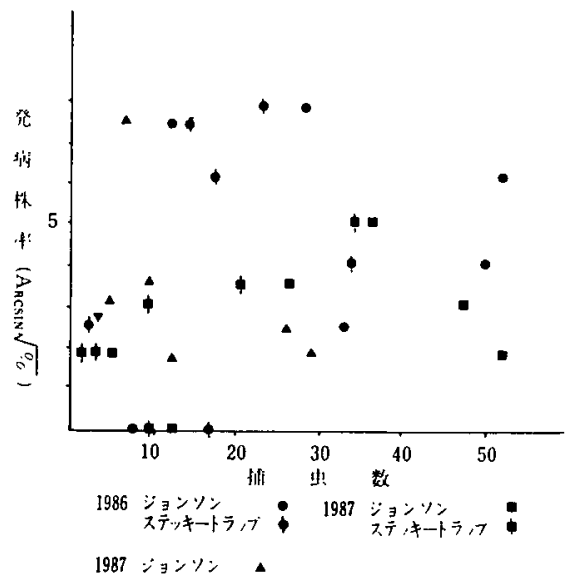

第 3 図ヒメトビウンカの地上 $10 \mathrm{~m}$ の捕虫数扰よびほ場侵人虫 数とイネ稿葉枯病発病の関係

第 1 表 ヒメトビウンカ第 1 世代の保毒率検定結果

\begin{tabular}{|c|c|c|c|}
\hline & 調 & 査 & 年 \\
\hline & 1986 & 1987 & 1988 \\
\hline 地点数 & 38 & 20 & 14 \\
\hline 平均保毒虫率 & $4.0 \%$ & $3.1 \%$ & $2.9 \%$ \\
\hline $\begin{array}{l}\text { 保瑇虫率 } \\
5 \% \text { 割合 }\end{array}$ & $37 \%$ & $35 \%$ & $21 \%$ \\
\hline
\end{tabular}

防除推進協議会 (とう写). 3) 新海 昭·宇杉富雄・中野 正明（1986）九病虫研会報 $33: 1-3.4$ ）安尾 俊. 石 井正義・山口富夫（1965）農事試報 $8: 17-108$.

(1989年5月 8 日 受領) 